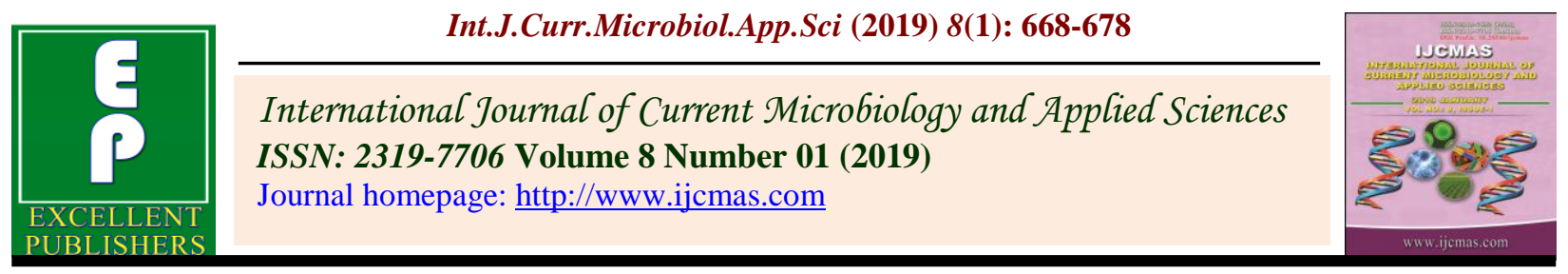

\title{
Association Study of Morphological and Physiological Traits with Yield in Groundnut Genotypes under Terminal Drought Condition
}

\author{
Mahesh R. Hampannavar ${ }^{*}$ and Hasan Khan ${ }^{2}$ \\ ${ }^{1}$ Department of Genetics and Plant Breeding, ${ }^{2}$ Groundnut Breeding, MARS, Raichur, \\ University of Agricultural Sciences, Raichur, College of Agriculture, Raichur- 584 104, India \\ *Corresponding author
}

\section{A B S T R A C T}

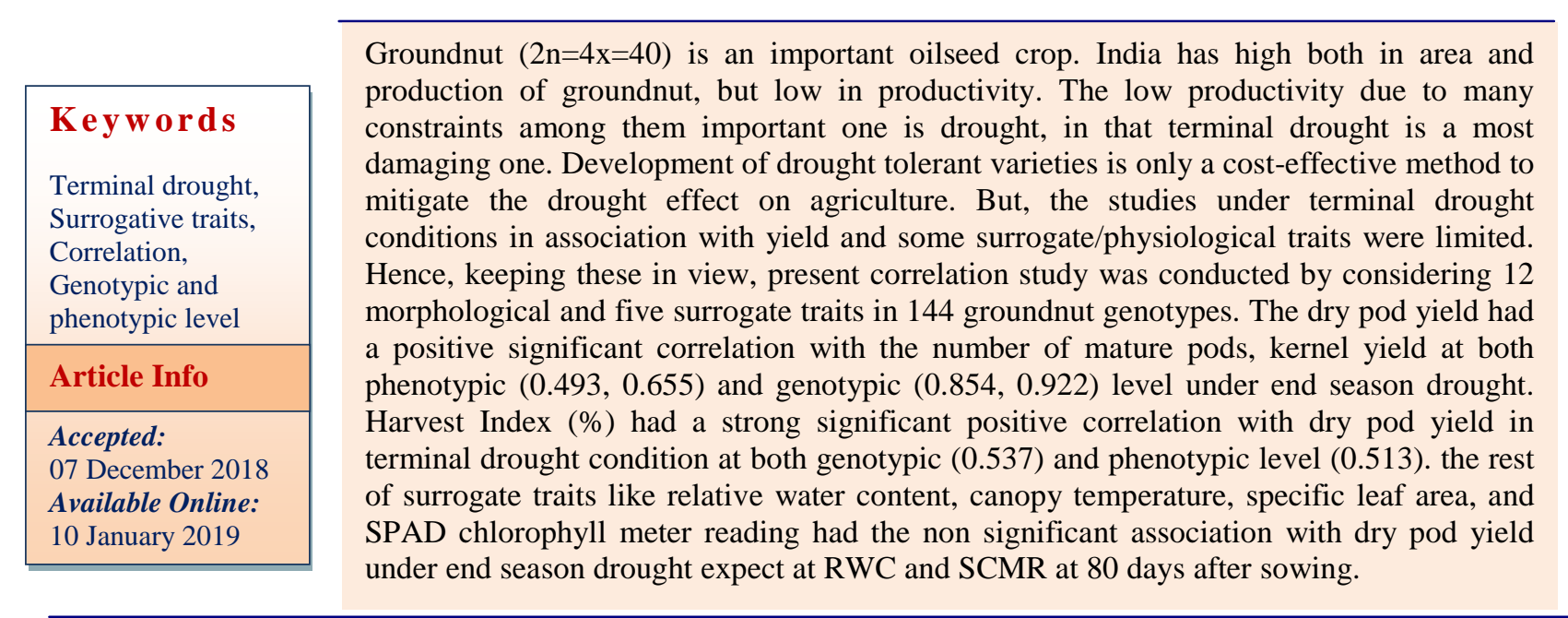

\section{Introduction}

The commercially cultivated Groundnut or peanut (Arachis hypogaea L.) is an allotetraploid $(2 n=4 x=40)$. The region of eastern foothills of Andes (Southern Bolivia and Northern Argentina) was the most probable centre of origin of groundnut. Peanut is widely utilize as an oil seed or food crop in more than 144 countries (includes tropical and warm temperate regions) of the world. The commercial production largely confined between $40^{\circ} \mathrm{N}$ and $40^{\circ} \mathrm{S}$ latitudes. India has high both in area and production of groundnut, but low in productivity. This is due to cultivation of the crop on marginal and submarginal lands (mainly under rainfed condition), biotic and abiotic stress and many socio-economic factors (Reddy et al., 1993). Among the numerous abiotic stresses the drought is major limitation for production. The rainfall is the most significant climatic factor affecting groundnut production in the arid and semi-arid region where the crop is 
raised mostly under rainfed conditions. There are three types of drought like early, mid and end season drought based on stage of drought during the crop production. The economic concern more loss from terminal drought condition. The adverse effect of end-season drought can be overcome by developing short duration varieties and breeding for drought tolerance varieties. The selection of tolerance varieties based on yield alone might be mislead the breeder because yield is complex trait which depends on many independent traits along with environment factor. Direct selection for yield under drought is effective but it is resource consuming and lacks of repeatability across different environments. Hence, to overcome these difficulties by using easily measurable surrogate or physiological trait like relative water content (RWC \%), specific leaf area (SLA), canopy temperature, SPAD chlorophyll meter reading (SCMR) etc., to decided use as selection criteria along with yield and yield components. Obviously, knowledge about character association with yield will surely aid selection for higher yield varieties. With a view to determine the extent and nature of relationship prevailing among yield contributing characters, an attempt has been made to study the character association in the 144 genotypes of groundnut both at phenotypic and genotypic levels under terminal drought condition.

\section{Materials and Methods}

The present investigation was initiated during kharif 2015 at Main Agriculture Research Station (MARS), University of Agriculture Sciences, Raichur, Karnataka, India. The field experiment conducted during kharif (August to December- 2015), on alfisol soil type. The weather data during experiment are presented in Table 1. The experimental material for the present study comprised of 144 groundnut genotypes (Table 2) which were collected from different institutes from across India.
The experiment was laid out in simple lattice design with two replications. Using a linesource sprinkler irrigation system, genotypes were screened for terminal drought tolerance ((Hanks et al., 1976). Soil moisture level maintained uniformly at field capacity (FC) from planting to 80 days after sowing (DAS). After 80 DAS (pod filling stage in groundnut) provide the irrigation through line source sprinkler method. The traits morphological traits like Days to $50 \%$ flowering, Plant height (cm), number of primary branch per plant, number Days to physiological maturity, number of mature pods per plant, number of Immature pods per plant, Shelling Percentage, Kernel yield, Sound Mature Kernel, Hundred Kernel Weight, Haulm yield per plant (g), Oil content, Dry pod yield per plant along with physiological traits like, relative water conduct, specific leaf area, SPAD chlorophyll meter reading, canopy temperature and harvest index were considered under the experiment. The first four physiological parameters recorded at 80, 90 and 100 days after sowing (DAS). The Both genotypic and phenotypic coefficients of correlation between all pairs of characters were determined by using variance and covariance components as suggested by Abraham et al., (1990).

\section{Results and Discussion}

Association of dry pod yield with its other yield attributing traits

The association between yield and 12 quantitative traits at genotypic and phenotypic level presented in Table 3. The dry pod yield had the positive significant correlation with number of mature pods, kernel yield at both phenotypic $(0.493,0.655)$ and genotypic $(0.854,0.922)$ level under end season drought. Whereas the traits like plant height $(0.221)$ and primary branches (0.201) had significant positive association only at genotypic level with dry pod yield. The sound mature kernel 
(0.14, 0.149), hundred kernel weight (0.091, $0.104)$ and haulm yield $(0.167,0.079)$ had the non-significant positive correlation at both phenotypic and genotypic level with dry pod yield The traits like days to $50 \%$ flowering ($0.209,-0.258)$ and oil content $(-0.194,-0.236)$ had significant negative correlation with dry pod yield at both genotypic and phenotypic level. The days to physiological maturity and shelling percentage had non-significant negative correlation at phenotypic (-0.038, $0.141)$ and genotypic (-0.048, -0.135) level. Whereas number of immature pods had significant negative correlation with yield at phenotypic level (-0.182) but shown the nonsignificant at genotypic level (-0.217).

\section{Association of physiological parameter with dry pod yield}

The results of association between physiological parameters with dry pod yield at genotypic and phenotypic are presented in Table 4. Harvest Index (\%) had strong significant positive correlation with dry pod yield in terminal drought condition at both genotypic (0.537) and phenotypic level (0.513). Relative water content (\%) had positive correlation with dry pod yield and only at 80DAS shown the significant positive correlation at both genotypic (0.242) and phenotypic (0.2033) correlation but not shown significant at RWC $90(0.0752,0.09)$ and 100 DAS $(0.0408,0.048)$. The correlation at genotypic and phenotypic level between canopy temperature and dry pod yield fallowed the similar result at 80,90 and 100 DAS. At 80 DAS (-0.021, -0.039) and 100 DAS (-0.042, -0.055) canopy temperature had non-significant negative correlation at genotypic and phenotypic with pod yield but at 90 DAS $(0.1089,0.124)$ it had nonsignificant positive correlation in terminal drought situations. The specific leaf area had non-significant positive correlation with dry pod yield at 80 DAS $(0.1295,0.157), 90$ DAS
$(0.1295,0.156)$ and 100 DAS $(0.1378,0.166)$ in control and end season drought at both genotypic and phenotypic correction levels. SPAD Chlorophyll Meter Reading (SCMR) had negative correlation with pod yield at 80 , 90 and 100 DAS in end season terminal drought condition at both genotypic and phenotypic level but only significant negative correlation seen in terminal drought condition at 90 DAS $(-0.2076,-0.236)$ in both levels.

In the present investigation the estimates of genotypic correlation was higher than those of phenotypic correlation for most of the traits. These higher genotypic values whenever observed were contributed to the relative stability of the genotypes (Davis et al., 1961). Thus trait with higher genetic correlation may throw light on validity of selection for those traits.

\section{Association of dry pod yield with its other yield attributing traits}

The dry pod yield had the positive significant correlation with number of mature pods, kernel yield at both phenotypic and genotypic level under end season drought. Obviously mature pods and kernel yield having direct association with and dry pod yield so it is one of the most suitable and widely used traits to identify the high yielding genotypes under terminal drought conditions. The results are in accordance with Kavani et al., (2004) and Shoba et al., (2012). The Jayalakshmi et al., (2000), Daboria et al., (2004) found the negative relation between oil content and seed yield. Due to end season drought oil content will reduced (Dwivedi et al., 1996).

Whereas the traits like plant height and primary branches had significant positive association only at genotypic level with dry pod yield. It indicates that under terminal drought condition plant height had strong direct proportional with yield so selection 
based on plant height will be rewarding under terminal drought condition drought condition. The primary branches helped in production of additional pod yield and can be used as selection criteria. The similar results were found by Venkataravan et al., (2000), Lakshmidevamma et al., (2004), Sirisha (2005) and Vasanti et al., (2015).

The days to physiological maturity, sound mature kernel, hundred kernel weight and haulm yield had the non-significant positive correlation at both genotypic and phenotypic level with dry pod yield. Sound mature kernels (SMK \%) indicates the percent of bold seeds. Hundred kernel weight (HKW) parameter help in determine the kernel size so SMK and HKW helps in develop the variety suitable for commercial cultivation. The drought susceptible varieties usually have the low SMK and HKW so these traits can also be used as criteria to select the tolerant genotypes. Some of the evidence for result is Reddi et al., (1991), Venkataravan et al., (2000), Roy et al., (2003) and Kavani et al (2004). Under stress condition or water limited situation biological yield had negative correlation because most of absorbed water is utilized to maintain the vegetative growth under stress condition (Kavani et al., 2004, Moinuddin, 1997).
The some traits like days to $50 \%$ flowering and shelling percentage had non-significant negative correlation with dry pod yield at both genotypic and phenotypic level. Similar result found by Vasanthi et al., (1998) and Suneetha et al., (2005) and contrary to above result reported by Lakshmidevamma et al., (2004). whereas number of immature pods had significant negative correlation with yield at phenotypic level but shown the nonsignificant at genotypic level. The negative association of immature pod with yield indicates that always select the genotypes which produce the less immature pods for improvement of yield. Under terminal drought condition select the genotypes with less number of immature pod productions as a drought tolerant variety. The similar result found by Pallas et al., (1979) and Yao et al (1982).

\section{Association between physiological and yield related traits}

Harvest index is proportion of pods to total biomass; it can vary depending upon timing and severity of water deficit relative to pod set (Ong et al., 1986). During kharif HI had strong significant positive correlation with dry pod yield both conditions at both genotypic and phenotypic levels.

Table.1 Meteorological data during 2015-16 at MARS, Raichur

\begin{tabular}{|c|c|c|c|c|c|c|c|c|c|c|}
\hline Year & Month & $\begin{array}{c}\text { Max.T } \\
\left({ }^{\circ} \mathrm{c}\right)\end{array}$ & $\begin{array}{l}\text { Min.T } \\
\left({ }^{\circ} \mathbf{c}\right)\end{array}$ & $\begin{array}{l}\mathbf{R F} \\
(\mathbf{m m})\end{array}$ & $\begin{array}{c}\text { Rainy } \\
\text { Day }\end{array}$ & $\begin{array}{c}\text { RH } \\
\text { I } \\
(\%)\end{array}$ & $\begin{array}{l}\text { RH } \\
\text { II } \\
(\%)\end{array}$ & Evporimeter & $\begin{array}{l}\text { Sunshain } \\
\text { Hours/day }\end{array}$ & $\begin{array}{l}\text { Wind } \\
\text { Spd } \\
(\mathbf{k} / \mathbf{h})\end{array}$ \\
\hline \multirow{6}{*}{2015} & July & 36.3 & 24.6 & 42.0 & 3 & 77 & 38 & 8.5 & 4.6 & 18.1 \\
\hline & August & 34.6 & 24.3 & 51.4 & 6 & 80 & 46 & 6.6 & 4.3 & 11.3 \\
\hline & September & 39.1 & 23.4 & 316.6 & 11 & 88 & 58 & 4.8 & 4.2 & 1.2 \\
\hline & October & 33.4 & 23.0 & 65.4 & 3 & 80 & 43 & 4.9 & 7.6 & 4.0 \\
\hline & November & 31.9 & 21.1 & 2.0 & 0 & 79 & 42 & 4.9 & 6.5 & 6.7 \\
\hline & December & 32.0 & 18.4 & 2.2 & 0 & 83 & 36 & 4.5 & 8.4 & 5.0 \\
\hline
\end{tabular}

Where, Max. $=$ maximum, Min. $=$ Minimum, $\mathrm{RF}(\mathrm{mm})=$ Rain fall $(\mathrm{mm}), \mathrm{RH}=$ Relative Humidity 
Table.2 List of groundnut (Arachis hypogaea L.) genotypes used during kharif and rabi/summer for screening

\begin{tabular}{|c|c|c|}
\hline Source & Genotypes & $\begin{array}{l}\text { No. of } \\
\text { genotypes }\end{array}$ \\
\hline \multirow[t]{2}{*}{$\begin{array}{l}\text { ICRISAT, } \\
\text { Patancheru, } \\
\text { Hyderbad, } \\
\text { Telangana. India }\end{array}$} & $\begin{array}{l}\text { Spanish types : series of ICGVs- } 99233,97092,93280,04018,02411,97058,15415,02317,3584,1342,97262, \\
04149,05036,02242,03043,99051,07227,01276,07120,13245,13241,1-13238,89104,01274,97182,39 \times 49- \\
81-1,06188,3102,06431,03397,03042,91114,98184,07166,07148,95070,03064,99052,96466,86015, \\
27 \times 49-12,02189,3343,4955,00343,06422,98105,4729,93470,07235,07270,07273,07286,07390,07392, \\
07395,07396,07296,07403,07404,07405,07406,07408,00350,02266,07222,99206,07220,95440,96172, \\
96155,99102,05193,07213,06227,07219,00440,00187,06423,06319,98163,99161,00201,99160,06189, \\
00189,95058,99210,05184 \text { and } 96153 \text { and CHICO }\end{array}$ & 91 \\
\hline & $\begin{array}{l}\text { Virginia types: Series of ICGVs- 01265, 01464, 9507, 05057, 00246, 05141, 03136, 01361, 05198, 07337, } 00247 \text {, } \\
07247,89178,00162 \text { and CS39 }\end{array}$ & 15 \\
\hline \multirow[t]{2}{*}{$\begin{array}{l}\text { BARC, Trombay, } \\
\text { Mumbai, India }\end{array}$} & $\begin{array}{l}\text { Spanish types: DTG-15, TG-49, TDG-51, TAG-24, TG-36, TG-37A, TG-47, TPG-41, TG-51, TG-72, TG-74, TG- } \\
\text { 75, TG-80 and TG-67 }\end{array}$ & 14 \\
\hline & Virginia type: Somanatha & 1 \\
\hline $\begin{array}{l}\text { TNAU, Coimbator, } \\
\text { India }\end{array}$ & Spanish type: TMV-2, & 1 \\
\hline \multirow{2}{*}{$\begin{array}{l}\text { PAU, Ludhian, } \\
\text { Punjab, India }\end{array}$} & Spanish types: 49-M-16 & 1 \\
\hline & Virginia type : M-28-2 & 1 \\
\hline $\begin{array}{l}\text { ARS, Kadiri } \\
\text { Hyderabad, India }\end{array}$ & Spanish types : K-6 and K- Harithendra & 2 \\
\hline \multirow{2}{*}{$\begin{array}{l}\text { UAS Dharawad, } \\
\text { Karnataka, India }\end{array}$} & Spanish types : GPBD-4, GPBD-5, Mutant-3, Dh-216 and G2-52 & 5 \\
\hline & Virginia types : DSG-41, TDG-39 and Dh-86 & 3 \\
\hline \multirow{2}{*}{$\begin{array}{l}\text { UAS Raichur, } \\
\text { Karnataka, India }\end{array}$} & Spanish types: R-8808, R-2001-2, KRG-01, SEL-01 Kadiri-9,ICGV 00351, and R-2001-3 & 7 \\
\hline & Virginia types : S-230 & 1 \\
\hline $\begin{array}{l}\text { UAS Bangalore, } \\
\text { Karnataka, India }\end{array}$ & Spanish type : Chintamani-2 & 1 \\
\hline $\begin{array}{l}\text { ZARS Tirupati, } \\
\text { Andha Pradesh, } \\
\text { India }\end{array}$ & Spanish type : Dharani & 1 \\
\hline
\end{tabular}


Table.3 Correlation co-efficient between yield and yield related traits in 144 groundnut genotype, during kharif under terminal drought

\begin{tabular}{|c|c|c|c|c|c|c|c|c|c|c|c|c|c|}
\hline & $\mathbf{X}_{1}$ & $\mathbf{X}_{2}$ & $\mathbf{X}_{3}$ & $X_{4}$ & $\mathbf{X}_{5}$ & $X_{6}$ & $\mathbf{X}_{7}$ & $\mathbf{X}_{8}$ & $X_{9}$ & $\mathbf{X}_{10}$ & $\mathbf{X}_{11}$ & $X_{12}$ & $\mathbf{X}_{13}$ \\
\hline $\mathbf{X}_{1}$ & 1 & $-0.355 * *$ & 0.113 & $0.318^{* *}$ & $-0.194 *$ & $0.181^{*}$ & -0.056 & $-0.230 * *$ & -0.109 & -0.0648 & $0.392 * *$ & $0.478 * *$ & $-0.209^{*}$ \\
\hline $\mathbf{X}_{2}$ & $-0.380 * *$ & 1 & 0.144 & -0.103 & 0.156 & -0.134 & -0.023 & 0.094 & -0.036 & 0.0262 & -0.007 & $-0.341 * *$ & 0.103 \\
\hline $\mathbf{X}_{3}$ & 0.121 & 0.161 & 1 & 0.157 & 0.108 & -0.149 & -0.148 & 0.055 & -0.084 & -0.0061 & $0.273 * *$ & 0.047 & 0.144 \\
\hline $\mathbf{X}_{4}$ & $0.334 * *$ & -0.105 & $0.177^{*}$ & 1 & -0.131 & -0.083 & -0.167 & -0.117 & 0.074 & $0.2533 * *$ & $0.237 * *$ & 0.054 & -0.038 \\
\hline$X_{5}$ & $-0.229 * *$ & $0.233 * *$ & $0.178^{*}$ & -0.166 & 1 & -0.057 & 0.023 & $0.489 * *$ & -0.135 & $-0.272 * *$ & -0.026 & -0.336 & $0.493 * *$ \\
\hline$X_{6}$ & $0.222 * *$ & -0.155 & $-0.173^{*}$ & -0.083 & -0.051 & 1 & -0.131 & $-0.211 *$ & $-0.328 * *$ & $-0.229 * *$ & $0.285^{* *}$ & 0.099 & $-0.182^{*}$ \\
\hline $\mathbf{X}_{7}$ & -0.092 & -0.028 & $-0.326 * *$ & $-0.262 * *$ & 0.094 & $-0.245 * *$ & 1 & $0.376 * *$ & 0.149 & 0.0682 & $-0.237 * *$ & -0.029 & -0.141 \\
\hline $\mathbf{X}_{8}$ & $-0.290 * *$ & $0.208^{*}$ & 0.075 & -0.137 & $0.691 * *$ & $-0.269 * *$ & $0.248 * *$ & 1 & $0.1835^{*}$ & 0.115 & 0.037 & $-0.213 *$ & $0.854 * *$ \\
\hline$X_{9}$ & -0.132 & -0.036 & -0.078 & 0.074 & $-0.185^{*}$ & $-0.361 * *$ & $0.240 * *$ & $0.200 *$ & 1 & $0.385^{* *}$ & -0.182 & 0.135 & 0.14 \\
\hline $\mathbf{X}_{10}$ & -0.093 & 0.032 & -0.007 & $0.255^{* *}$ & $-0.325 * *$ & $-0.237 * *$ & 0.12 & 0.138 & $0.404 * *$ & 1 & -0.129 & 0.087 & 0.091 \\
\hline $\mathbf{X}_{11}$ & $0.424 * *$ & 0.024 & $0.326^{* *}$ & $0.246^{* *}$ & -0.037 & $0.321 * *$ & $-0.360 * *$ & -0.047 & $-0.213^{*}$ & -0.139 & 1 & $0.277 * *$ & 0.167 \\
\hline$X_{12}$ & $0.459 * *$ & $-0.362 * *$ & 0.048 & 0.054 & $-0.401 * *$ & 0.118 & -0.045 & $-0.267 * *$ & 0.139 & 0.075 & $0.287 * *$ & 1 & $-0.194 *$ \\
\hline$X_{13}$ & $-0.258 * *$ & $0.221 * *$ & $0.201 *$ & -0.048 & $0.655 * *$ & -0.217 & -0.135 & $0.922 * *$ & 0.149 & 0.104 & 0.079 & $-0.236^{* *}$ & 1 \\
\hline
\end{tabular}

Significant at $5 \%=*$ and significant at $1 \%=* *$, Genotypic level $=$ down ward left side of diagonal, Phenotypic level $=$ upward ward right side of diagonal Where, $\mathrm{X}_{1}=$ Days to $50 \%$ flowering, $\mathrm{X}_{2}=$ Plant height $(\mathrm{cm}), \mathrm{X}_{3}=$ No. of primary branch per plant, $\mathrm{X}_{4}=$ Days to physiological maturity, $\mathrm{X}_{5}=$ No. of mature pods per plant, $\mathrm{X}_{6}=$ No. of Immature pods per plant $\mathrm{X}_{7}=$ Shelling Percentage, $\mathrm{X}_{8}=$ Kernel yield, $\mathrm{X}_{9}=$ Sound Mature Kernel, $\mathrm{X}_{10}=$ Hundred Kernel Weight, $\mathrm{X}_{11}=$

Haulm yield per plant $(\mathrm{g}), \mathrm{X} 12=$ Oil content, $\mathrm{X}_{13}=$ Dry pod yield per plant $(\mathrm{g})$. 
Table.4 Correlation co-efficient between yield and physiological traits in 144 groundnut genotype, during kharif under terminal drought

\begin{tabular}{|c|c|c|c|c|c|c|c|c|c|c|c|c|c|c|}
\hline & $\mathrm{Z}_{1}$ & $\mathbf{Z}_{2}$ & $\mathbf{Z}_{3}$ & $\mathbf{Z}_{4}$ & $\mathbf{Z}_{5}$ & $\mathrm{Z}_{6}$ & $\mathbf{Z}_{7}$ & $\mathbf{Z}_{8}$ & $\mathbf{Z}_{9}$ & $\mathrm{Z}_{10}$ & $Z_{11}$ & $Z_{12}$ & $Z_{13}$ & $X_{13}$ \\
\hline $\mathrm{Z}_{1}$ & 1 & -0.078 & -0.142 & -0.12 & -0.005 & 0.042 & -0.019 & 0.053 & 0.053 & 0.057 & $-0.36 * *$ & $-0.385 * *$ & $-0.33 * *$ & $0.513 * *$ \\
\hline $\mathbf{Z}_{2}$ & -0.079 & 1 & $0.409 * *$ & $0.285^{* *}$ & -0.004 & 0.127 & 0.036 & 0.138 & 0.138 & 0.138 & 0.139 & 0.132 & 0.088 & $0.2033^{*}$ \\
\hline $\mathbf{Z}_{3}$ & -0.145 & $0.405 * *$ & 1 & $0.407 * *$ & 0.095 & $0.223 * *$ & $0.195^{*}$ & $0.242 * *$ & $0.241 * *$ & $0.243 * *$ & 0.082 & 0.109 & 0.134 & 0.0752 \\
\hline $\mathbf{Z}_{4}$ & -0.123 & $0.283 * *$ & $0.406 * *$ & 1 & 0.132 & $0.193^{*}$ & $0.208^{*}$ & 0.128 & 0.128 & 0.129 & -0.017 & 0.012 & 0.006 & 0.0408 \\
\hline $\mathbf{Z}_{5}$ & -0.011 & -0.037 & 0.08 & 0.13 & 1 & $0.233 * *$ & 0.133 & 0.168 & 0.167 & 0.162 & -0.005 & 0.102 & 0.112 & -0.021 \\
\hline$Z_{6}$ & 0.043 & 0.11 & $0.217 *$ & $0.192 *$ & $0.153^{*}$ & 1 & $0.848 * *$ & $0.221 * *$ & $0.22 * *$ & $0.223 * *$ & -0.067 & -0.074 & -0.064 & 0.1089 \\
\hline $\mathbf{Z}_{7}$ & -0.022 & 0.02 & $0.188^{*}$ & $0.207 *$ & 0.063 & $0.841 * *$ & 1 & 0.117 & 0.117 & 0.115 & -0.001 & 0.044 & 0.003 & -0.042 \\
\hline $\mathbf{Z}_{8}$ & 0.058 & 0.128 & $0.236 * *$ & 0.124 & 0.15 & $0.208^{*}$ & 0.103 & 1 & 1 & $0.999 * *$ & $-0.193 *$ & -0.151 & -0.073 & 0.1295 \\
\hline$Z_{9}$ & 0.058 & 0.128 & 0.236 & 0.125 & 0.15 & $0.209 *$ & 0.103 & 1 & 1 & $0.999 * *$ & $-0.194 *$ & -0.152 & -0.074 & 0.1295 \\
\hline$Z_{10}$ & 0.062 & 0.129 & $0.237 * *$ & 0.126 & 0.146 & $0.212^{*}$ & 0.102 & $0.999 * *$ & $0.999 * *$ & 1 & -0.201 & -0.159 & -0.076 & 0.1378 \\
\hline $\mathrm{Z}_{11}$ & $-0.378 * *$ & 0.122 & 0.069 & -0.027 & -0.063 & -0.111 & -0.033 & $-0.220 * *$ & $-0.220 * *$ & $-0.226 * *$ & 1 & $0.813 * *$ & $0.679 * *$ & -0.1495 \\
\hline$Z_{12}$ & $-0.401 * *$ & 0.113 & 0.096 & 0.003 & 0.048 & -0.124 & 0.012 & $-0.180 *$ & $-0.180 *$ & $-0.186^{*}$ & $0.806 * *$ & 1 & $0.760 * *$ & $\begin{array}{c}- \\
0.2076^{*}\end{array}$ \\
\hline $\mathbf{Z}_{13}$ & $-0.351 * *$ & 0.065 & 0.12 & -0.004 & 0.053 & -0.118 & -0.035 & -0.103 & -0.103 & -0.103 & $0.665^{* *}$ & $0.749 * *$ & 1 & -0.1489 \\
\hline $\mathbf{X}_{13}$ & $0.537 * *$ & $0.242 * *$ & 0.09 & 0.048 & -0.039 & 0.124 & -0.055 & 0.157 & 0.156 & 0.166 & -0.167 & $-0.236 * *$ & -0.167 & 1 \\
\hline \multicolumn{15}{|c|}{ significant at $5 \%=*$ and significant at $1 \%=* *$ Genotypic level $=$ down ward left side of diagonal, Phenotypic level = upward ward right side of diagonal } \\
\hline & $\mathrm{O}$ & 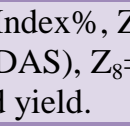 & 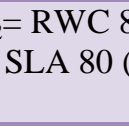 & 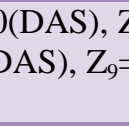 & & 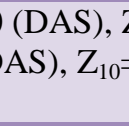 & & $N^{2}$ & Cano & $m x^{\circ}$ & C) 7 & anopy & 0 & ),$Z_{7}=$ \\
\hline
\end{tabular}


So genotypes which record the high value of HI (\%) under terminal drought conditions can use as stress tolerance parameter (Rathnakumar and Vadez, 2011). The similar study found by Sharma and Vershney (1995), Jayalakshmi et al., (1999) and Jongrungklang et al., (2008). Relative Water Content (RWC\%) had positive correlation with dry pod yield at phenotypic level and genotypic level. Only RWC at 80DAS had shown the significant positive correlation not at RWC 90 and 100 DAS. The same result arrived in genotypic level correlation. Relative water content helps to know the retention capacity of water under normal and drought condition. It is one of the water use efficiency and drought tolerant physiological parameter. The groundnut genotypes with high RWC under terminal drought had high higher pod yield (Koolachart et al, 2013). The healthy plant maintains the low canopy temperature compare to terminal drought imposed plant due to more transpiration and cooling effect. At 80 DAS and 100 DAS canopy temperature had non-significant negative with pod yield in contrary non-significant positive correlation at 90 DAS. The result indicates that select the genotype with low canopy temperature under terminal drought as tolerant genotype. Hence it is an important indirect and handy parameter to screen against terminal drought tolerant. The Specific Leaf Area (SLA) had non-significant positive correlation with dry pod yield at 80, 90 and 100 DAS at both genotypic and phenotypic correction levels. Similarly it is reported by Jayalakshmi et al., (1999). Usually under drought stress plant reduces leaf area which helps in reduce the area for transpiration and increase the thickness of leaves which helps in retention of more water. The SLA had negative correlation with SCMR and positive correlation with RWC. The similar results found by Vasanthi et al., (1998), Nageshwar Rao et al., (2001), Nautiyal et al., (2002), Upadhaya (2005), Nigam et al (2008),
Jungruklang et al., (2008), Koolachart et al (2013) and Basu and Nautiyal (2008). The SPAD Chlorophyll Meter Reading had negative correlation with pod yield at 80, 90, 100 DAS in end season stress condition at both genotypic and phenotypic level but only significant negative correlation seen in terminal drought condition at 90 DAS in both levels. The SCMR value had negative correlation with SLA under stress condition. The similar results were found by Moreshet et al., (1990), Vasanthi et al., (1998), Nageshwar Rao et al., (2001), Nautiyal et al., (2002), Upadhaya (2005), Nigam et al., (2008), Jungruklang et al., (2008), Koolachart et al (2013) and Basu and Nautiyal (2008).

Association studies assist in selection of superior line though effortless and indirect way. The association of various morphological and physiological traits helps in selection of terminal drought tolerant genotypes. Some of parameters like kernel weight, number of mature pods, plant height, number of primary branches, number of immature pods, harvest index and SPAD chlorophyll meter reading are promising traits in during the selection of terminal drought genotypes.

\section{Acknowledgement}

This research was partially supported by head of department crop physiology Dr. Amaregouda AC Raichur who provided laboratory facility which greatly assisted the research. We thank Dr. B. V. Temburne and P. Janila for comments that greatly improved the manuscript. We would also like to show our gratitude to staffs of Main Agricultural Research Station Raichur.

\section{References}

Abraham, M. J. 1990. Correlation, path and discriminate function analysis in 
groundnut grown on a $\mathrm{P}$ - deficient acid soil. Crop Improv. 17: 34-37.

Basu, M. S. and Nautiyal, P. C. 2008. Improving water use efficiency and drought tolerance in groundnut by trait based breeding programmes in India. In: $4^{\text {th }}$ international crop science congress.

Daboria, J. R., A. L. Rathnakumar and Bharodia, P. S. 2004. Genetic analysis of yield components and confectionery traits in crosses involving large seeded genotypes of groundnut (Arachis hypogaea L.). Journal of Oilseeds Res. 21: 11-16.

Davis, W. H., G. K. Middleton and Hebert, T. T. 1961. Inheritance of protein, texture and yield in wheat. Crop Sci. 1: 235238.

Dwivedi, S. L., S. N. Nigam, R. C. Nageswar Rao, U. Singh and Rao, K. V. S. 1996. Effect of drought on oil, fatty acid and protein contents of groundnut (Arachis hypogaea L.) seeds. Field. Crop Res. 48: $125-138$.

Hanks, R. J., J. Keller, V. P. Rasmussen and Wilson, C. D. 1976. Line source sprinkler for continuous variable irrigation- crop production studies. Soil Science Society of America Proceeding, 40: 426-429.

Jayalakshmi, V., C. Raja Reddy, P. V. Reddy and Nageshwara Rao, R. C. 1999. Genetic analysis of carbon isotope discrimination and specific leaf area in groundnut (Arachis hypogaea L). Journal Oilseeds Res. 16 (1): 1-5.

Jayalakshmi, V., C. R. Reddy, P. V. Reddy and Reddy, G. L. K. 2000. Character association among morphological attributes in parental genotypes and groundnut hybrids. Legume Res. 23: 102-105.

Jongrungklang, N., N. Toomsan, N. Vorasoot, N. Jogloy, T. Kesmala and Patanothai, A. 2008. Identification of Peanut Genotypes with High Water Use
Efficiency under Drought Stress Conditions from Peanut Germplasm of Diverse Origins. Asian Journal Pl. Sci. 7: 628-638.

Jongrungklang, N., N. Toomsan, N. Vorasoot, N. Jogloy, T. Kesmala and Patanothai, A. 2008. Identification of Peanut Genotypes with High Water Use Efficiency under Drought Stress Conditions from Peanut Germplasm of Diverse Origins. Asian J. Pl. Sci. 7: 628-638.

Kavani, R. H., P. R. Golakia, V. G. Makne and Madaria, R. B. 2004 Genetic variation and trait associations in Valencia groundnut (Arachis hypogaea L.). In: Proceedings of National symposium on enhancing productivity of groundnut for sustaining food and nutritional security, NRCG, Junagadh. Pp: 5

Koolachart, R., B. Suriharn, S. Jogloy, N. Vorasoot, S. Wongkaew, C. C. Holbrook, N. Jongrungklang, T. Kesmala and Patanothai, A. 2013. Relationships between physiological traits and yield components of groundnut genotypes with different levels of terminal drought resistance. SABRAO J. Breed. Genet. 45(3): 422446.

Lakshmidevamma, T. N., M. Byregowda and Mahadevu, P. 2004. Character association and path analysis in groundnut (Arachis hypogaea L.). Mysore J. Agric. Sci. 38:221-226.

Moinuddin, H. H., 1997, Evaluation of genotype $\mathrm{x}$ environment interaction in groundnut (Arachis hypogaea L.) genotypes. M.Sc. (Ag.) Thesis submitted to UAS, Bangalore, Karnataka.

Moreshet, S., Y. Cohen, G. S. Green and Fuchs, M. 1990. The partitioning of hydraulic conductance within mature orange trees. J. Exp. Bot. 41, 833-839.

Nageswara Rao, R. C., H. S. Talwar and 
Wright, G. C. 2001. Rapid assessment of specific leaf area and leaf nitrogen in Peanut (Arachis hypogaea L.) using a chlorophyll meter. J. Agron. Crop Sci. 189: 175-182.

Nautiyal, P. C., R. C. Nageshwara Rao and Joshi, Y. C. 2002. Moisture-deficitinduced changes in leaf-water content, leaf carbon exchange rate and biomass production in groundnut cultivars differing in specific leaf area. Field Crops Res. 74: 67-79.

Nigam, S. N. and Rupakula, A. 2008. Stability of soil plant analytical development (SPAD) chlorophyll meter reading (SCMR) and specific leaf area (SLA) and their association across varying soil moisture stress conditions in groundnut (Arachis hypogaea L.). Euphytica. 160: 111-117.

Ong, 1986. Agroclimatological factors affecting phenology of groundnut. Proceedingof international Symposium, ICRISAT, Patancheru. Andhra pradesh India, Pp: 115-126.

Pallas, J. E., J. R. Stansell, R. R. Bruce and Koske, T. J. 1979. Effect of drought on Florunner peanuts. Agron. J. 71: 853858.

Ratnakumar, P and Vadez, V. 2011. Groundnut (Arachis hypogaea L.) genotypes tolerant to intermittent drought maintain a high harvest index and have small leaf canopy under stress. Functional Pl. Bio. 38: 1016-1023.

Reddi, M. V., K. R. Reddy, K. H. P. Reddy and Rao, J. A. 1991. Heritability, genetic advance and character association in groundnut over three environments. J. Maharashtra. Agric. Univ. 16 (3): $383-385$.

Reddy, L. J., S. N. Nigam and Nageswara Rao, R. C. 1993. Progress in breeding for drought tolerant groundnut varieties at ICRISAT centre. In National level seminar on oilseeds research and development in India: status and strategies. Pp: 50-51.

Roy, D., R. K. Patel and Ojha, O. P. 2003. Study on podding index and other traits in groundnut (Arachis hypogaea L.). Legume Res. 26 (4): 310 -312.

Sharma, V. K. and Varshney, S. K. 1995. Analysis of harvest index in groundnut. J. OilSeeds Res., 12: 171-175.

Shoba, D., N. Manivannan and Vindhiyavarman, P. 2012. Correlation and path coefficient analysis in Groundnut (Arachis hypogaea L.). Madras Agric. J. 99 (1-3): 18-20.

Sirisha, P., 2005. Genetic studies in $F_{3}$ and $F_{4}$ generations of five crosses in grounndut (Arachis hypogaea L.). M.Sc. (Ag.) Thesis, Acharya N.G. Ranga Agricultural University, Hyderabad.

Suneetha, K., Dasarada, C. Rami and Ramana, J. V. 2004. Genetic variability and character association in groundnut, National Symposium On Enhancing Productivity of Groundnut for Sustaining Food and Nutritional Security 11-13 October-2004 NRCG, Junagadh. Pp: 1.

Upadhyaya, H. D., 2005. Variability for Drought Resistance Related Traits in the Mini Core Collection of Peanut. Crop Sci. 45:1432-1440.

Vasanthi, R. P., N. P. Harinath and Sudhakar, R. A. 1998. Genetic variability and correlation of yield component traits and foliar disease resistance in groundnut. J. Oilseeds Res. 15: 345347.

Vasanthi, R. P., P Harinatha Naidu and Sudhakar Rao, A. 1998. Inter relation among yield, yield attributes and late leaf spot severity in groundnut. J. Oilseeds Res. 15 (2): 383 - 385.

Vasanti, R. P., N. Suneetha and Sudhakar, P. 2015. Genetic variability and correlation studies for morphological, yield and yield attributes in groundnut 
(Arachis hypogaea L.). Legume. Res. 38(1): 9-15.

Venkataravana, P., R. A. Sheriff, R. S. Kulkarni, V. Shankaranarayana and Fathima P. S. 2000. Correlation and path analysis in groundnut (Arachis hypogaea L.). Mysore J. Agric Sci. 34
(4): 321325.

Yao, J.P., Y. N. Luo and Yang, X. D. 1982. Preliminary report on the effect of drought on seed development and quality of early groundnut. Chinese Oil Crops. 3: 50-53.

\section{How to cite this article:}

Mahesh R. Hampannavar and Hasan Khan. 2019. Association Study of Morphological and Physiological Traits with Yield in Groundnut Genotypes under Terminal Drought Condition. Int.J.Curr.Microbiol.App.Sci. 8(01): 668-678. doi: https://doi.org/10.20546/ijcmas.2019.801.075 